\title{
Persistence and efficacy of a new formulation based on dog allomonal repellents against Rhipicephalus sanguineus sensu lato tick
}

\author{
Persistência e eficácia de uma nova formulação baseada em repelentes alomônios de cães contra \\ o carrapato Rhipicephalus sanguineus sensu lato
}

Jaires Gomes de Oliveira Filho' ${ }^{1}$, Lorena Lopes Ferreira ${ }^{1}$; Fernanda de Oliveira Silva ${ }^{1}$;

Karolina Martins Ferreira Menezes' ${ }^{1}$; Elen Regozino Muniz ${ }^{1}$; Luiza Gabriella Ferreira de Paula';

André Lucio Franceschini Sarriaa² John Anthony Pickett ${ }^{2}$; Michael Alexander Birkett ${ }^{2}$; Gabriel Moura Mascarin³; Lígia Miranda Ferreira Borges ${ }^{4 *}$

\author{
${ }^{1}$ Escola de Veterinária e Zootecnia, Universidade Federal de Goiás - UFG, Campus Samambaia, Goiânia, GO, Brasil \\ ${ }^{2}$ Biointeraction and Crop Protection Department, Rothamsted Research, West Common, Harpenden, Hertfordshire, AL5 2JQ, \\ United Kingdom \\ ${ }^{3}$ Empresa Brasileira de Pesquisa Agropecuária - Embrapa Meio Ambiente, Jaguariúna, SP, Brasil \\ ${ }^{4}$ Instituto de Patologia Tropical e Saúde Pública, Universidade Federal de Goiás - UFG, Goiânia, GO, Brasil
}

Received February 26, 2018

Accepted June 12, 2018

\begin{abstract}
Beagles are less susceptible to Rhipicephalus sanguineus sensu lato tick due to the production of the allomones benzaldehyde and 2-hexanone. Our previous published work showed that these compounds can reduce tick burden on susceptible dogs. Here we tested the hypothesis that an increase in repellent dose and release rate could increase repellent efficacy and persistence. Slow-release formulations of these compounds, with higher doses and release rates, were tested on artificially-infested dogs. Ten dogs were randomly assigned to two groups with five dogs each. The treated group received collars with slow-release formulations of the compounds attached, while the control group received collars with clean formulations attached. Five environmental infestations were performed, with the number of ticks (at all stages) on the dogs being counted once a day for 40 days. No significant increase in repellent efficacy was observed with the higher doses and release rates, whereas a greater persistence in repellent activity was observed. Treatment with the formulations resulted in a two-to-three-fold reduction in the number of immature stage ticks for up to three weeks. However, the number of adults was similar in both groups. Loss of repellent activity after the third week of testing coincided with a marked change in the relative release rates for the two compounds. It is hypothesized that relative amounts, rather than absolute amounts, of repellent release from slow-release formulations are important for repellent activity. We also hypothesize that the avoidance of less-preferred hosts by ticks relies on olfactory-mediated perception of specific blends of volatile cues from less preferred hosts.
\end{abstract}

Keywords: Benzaldehyde, 2-Hexanone, slow release formulation, tick control.

\section{Resumo}

Beagles são menos suscetíveis ao carrapato Rhipicephalus sanguineus sensu lato devido à produção de benzaldeído e 2-hexanona. Nosso trabalho anterior já publicado mostrou que esses compostos podem reduzir a carga de carrapatos em cães suscetíveis. Aqui testamos a hipótese de que um aumento na dose destes repelentes e na taxa de liberaçáo poderia aumentar a eficácia e a persistência do efeito repelente. As formulaçôes de liberação lenta destes compostos, com doses e taxas de liberação mais elevadas foram testadas em cães infestados artificialmente. Dez cães foram distribuídos aleatoriamente em dois grupos com cinco cáes cada. O grupo tratado recebeu colares contendo formulaçôes de liberação lenta dos compostos, enquanto o grupo controle recebeu colares com formulações limpas. Cinco infestações ambientais foram realizadas, com o número de carrapatos (em todas as fases) nos cães sendo contados, uma vez ao dia, por 40 dias.

\footnotetext{
${ }^{*}$ Corresponding author: Lígia Miranda Ferreira Borges. Instituto de Patologia Tropical e Saúde Pública, Universidade Federal de Goiás - UFG, Rua 235, s/n, Setor Universitário, CEP 74605-050, Goiânia, GO, Brasil. e-mail: borges.ligia@gmail.com
} 


\begin{abstract}
Não se observou aumento significativo na eficácia do repelente com doses e taxas de liberação mais elevadas e, enquanto observou-se maior persistência na atividade repelente. $\mathrm{O}$ tratamento com as formulações resultou em uma redução de duas a três vezes no número de carrapatos dos estágios imaturos, por até três semanas. No entanto, o número de adultos foi semelhante em ambos os grupos. A perda de atividade repelente após a terceira semana de teste coincidiu com uma mudança nas taxas de liberaçáo relativa para os dois compostos. A hipótese é que as quantidades relativas, ao invés das quantidades absolutas de liberação lenta, são importantes para a atividade repelente. Então, a hipótese é de que a repelência apresentada por hospedeiros menos susceptíveis aos carrapatos depende da percepção pelos carrapatos de misturas específicas de voláteis liberados por estes hospedeiros.
\end{abstract}

Palavras-chave: Benzaldeído, 2-Hexanona, formulação de liberação lenta, controle de carrapatos.

\section{Introduction}

The brown dog tick, Rhipicephalus sanguineus sensu lato (Acari: Ixodidae), is an important vector of pathogens for companion animals as well as for human beings (SONENSHINE \& ROE, 2014). Management of $R$. sanguineus s.l. currently requires the use of costly acaricides, but the development of resistance in $R$. sanguineus s. 1. populations has been reported (GRAF et al., 2004; EIDEN et al., 2015; RODRIGUEZ-VIVAS et al., 2017). Therefore, there is an urgent need to find alternative tools for $R$. sanguineus s. l. management that either slow the rate of resistance development and dependence upon acaricide use altogether.

There are several reports that animals within the same species, or of different species, carry different ectoparasitic loads due to variation in the composition of volatile organic compounds (VOCs) that they emit. This differential production signals to ectoparasites that animals are either more suitable (more susceptible) or less suitable (less susceptible) as hosts (PICKETT et al., 2010). Cattle flies, Haematobia irritans, are differentially attracted to susceptible bovine hosts, Bos taurus taurus within herds, due to differences in VOC emission, with less suitable hosts producing higher levels of VOCs (allomones) that possess repellent activity (JENSEN et al., 2004; BIRKETT et al., 2004). The production of allomones by the non-host waterbuck, Kobus defassa, against tsetse flies, Glossina morsitans, has also been demonstrated (BETT et al., 2015). Recently, we demonstrated that larvae of the cattle tick Rhipicephalus microplus are less responsive to the odours of resistant bovine hosts, Bos taurus indicus, compared to odours from susceptible Bos taurus taurus (BORGES et al., 2015a).

In our seminal work on dog tick / host interactions (LOULY et al., 2009), when comparing the susceptibility of two breeds of dogs to $R$. sanguineus s. l., we observed that beagles were less parasitized than English cocker spaniels, partially due to the production of allomones by beagles (LOULY et al., 2010; BORGES et al., 2015b). More recently, work elsewhere observed differences in susceptibility to R. sanguineus s. l. between different breeds of dogs, with the English cocker spaniel being more parasitized by this tick when compared to other breeds (SILVA, 2016). Subsequently, we identified two compounds produced by less-susceptible beagles, benzaldehyde and 2-hexanone, as allomones responsible for the lower susceptibility of these dogs to $R$. sanguineus s. l. (BORGES et al., 2015b).

Previously we showed that by attaching slow-release formulations of 2-benzaldehyde and 2-hexanone to collars, we could reduce the number of ticks on dogs (OLIVEIRA et al., 2017), thus providing the first demonstration of using an allomonal repellent formulation to reduce tick infestation on susceptible dogs. In this new study, we evaluated the persistence and efficacy of a new allomonal formulation that emitted higher release rates of the two compounds, compared to the formulations tested by us previously, for reducing $R$. sanguineus s. l. loads on English cocker spaniels.

\section{Material and Methods}

\section{Animals}

Ten English cocker spaniels were divided into two groups, treated and untreated. To avoid any specific group having greater tick numbers, animals were distributed as follows. After the first infestation and tick counts (see item 2.4), the animals were ranked from the higher to the lower tick load. The two animals having the highest number of ticks were randomly allocated in one of the groups, treated or untreated. The same procedure was done with the following two dogs in rank and then successively until all animals are allocated in one group. Each group containing five dogs (four males and one female; $94 \pm 10.02$ days old), was housed in two stalls $\left(2 \mathrm{~m}^{2}\right)$, with the three smallest animals being housed in one stall and the two largest animals housed in the other. The use of animals (dogs and rabbits) in this study was approved by the Committee on Ethical Animal Use of the Federal University of Goiás (CEUA/UFG, protocol number 024/2014).

\section{Ticks}

Engorged female brown dog ticks, $R$. sanguineus s. 1., were harvested from naturally infested dogs from the municipality of Goiânia, Goiás, Brazil, for the establishment of a tick colony. The ticks were maintained in an acclimatized chamber $\left(27 \pm 1{ }^{\circ} \mathrm{C}\right.$ and $80 \%$ R.H.) and fed on rabbits, Oryctolagus cuniculus, to obtain differing life stages for use in dog infestations. The ticks used in the experiments were aged between one and three weeks old after eclosion. Rabbits were removed from use after two consecutive infestations. During infestations, rabbits were examined daily and none showed symptoms of damage due to tick parasitism.

\section{Slow-release formulations}

Sheets of cellulose sponge $(\sim 3 \times 3 \mathrm{~cm}$, Al Packaging Ltd., London film type LFT size $50 \mathrm{~mm}$ gauge and $62.5 \mathrm{mic}$ lift) were treated with benzaldehyde $(2 \mathrm{~mL})$ and 2-hexanone $(1 \mathrm{~mL})$ and heat-sealed in polyethylene tubing (1000 gauge). The mean release rate per day of the compounds from the sachet formulations was determined over five weeks using dynamic headspace collection 
(air entrainment) and Gas Chromatography analysis. Thus, three sachets filled with either benzaldehyde or 2-hexanone were enclosed in a glass vessel $(700 \mathrm{~mL})$. Air was pumped through an activated charcoal filter into the vessel $(1 \mathrm{~L} / \mathrm{min})$ and was then drawn $(500 \mathrm{~mL} / \mathrm{min})$ into glass tubes containing Porapak Q $(50 \mathrm{mg})$. After one hour, collected volatiles were eluted with $750 \mathrm{uL}$ of redistilled diethyl ether and the samples were stored at $-20{ }^{\circ} \mathrm{C}$ until required for GC analysis. Extracts $(1 \mathrm{uL})$ were analysed on an Agilent $6890 \mathrm{~N}$ GC fitted with a $10 \mathrm{~m} \times 0.32 \mathrm{~mm}$ i.d. HP-1 column and a flame ionization detector (FID). The oven temperature was maintained at $30^{\circ} \mathrm{C}$ for $0.1 \mathrm{~min}$ (6 seconds), then programmed at $10^{\circ} \mathrm{C}$ min -1 to $250^{\circ} \mathrm{C}$ and held for $30 \mathrm{~min}$. It was observed that for benzaldehyde, the release rate was more or less constant and varied between 48.25 to $61.82 \mu \mathrm{g} /$ day. However, for 2-hexanone, the release was only constant in the first 3 weeks, ranging from 38.33 to $55.28 \mu \mathrm{g} /$ day, decreasing sharply in the fourth week to $8.53 \mu \mathrm{g} /$ day. The release ratio between benzaldehyde and 2-hexanone ranged from 1.18 to 1.61 in the first 3 weeks, which was reasonably close to that found naturally in beagles by Oliveira et al. (2016). In the fourth week, the ratio was 6.41 and different from that observed in Oliveira et al. (2016).

\section{Tick infestation and counting}

Every week, for 35 days, 4000 larvae, 200 nymphs and 60 adults (30 males and 30 females) were released onto the walls of each stall, totalling six artificial infestations. The number of ticks was stipulated in our previous work, but with an increase in the number of immature stages (OLIVEIRA et al., 2017). Collars containing the sachets with benzaldehyde and 2-hexanone were placed simultaneously with the second infestation and withdrawn after the fifth infestation. Two days after the first infestation, dogs were inspected once a day at 16:00h for 40 days. Dogs were simultaneously inspected by two trained personnel for tick counts using a magnifying glass, $1.5 \mathrm{x}$ to $10 \mathrm{x}$, with a led light (Led headhand magnifier model MG811007- A, China) to help visualize the ticks. A map of 24 body areas, including $R$. sanguineus s. 1 . sites, was used to standardize tick counts. The final number of ticks per day was determined by the maximum ticks per area found in one day, and the counts represented the total of ticks found per dog during a week (OLIVEIRA et al., 2017). Ticks were not removed during inspections. This experiment was carried out in September and October 2016, where the measured temperature ranged from $19{ }^{\circ} \mathrm{C}$ to $31{ }^{\circ} \mathrm{C}$.

\section{Statistical analysis}

Count data for larvae, nymphs and adults were separately fitted to a negative binomial model, since this model gave the best goodness-of-fit based on Akaike information criterion and half-normal plot criteria for model selection (MORAL et al., 2017). Treatment, infestation date and their interaction term were included in the model as predictors while each dog was considered as a biological repetition and an overdispersion parameter was also accounted in each model. Significant differences between treated $v$ s. control dogs were determined by Likelihood Ratio (LR) chi-square test for each infestation date. Analysis was carried out using R statistical software environment (R CORE TEAM, 2015).

\section{Results}

In the week before animals received repellent collars, the number of larvae, nymphs and adults was similar in treated and control groups (larvae $p=0.3392$; nymphs $p=0.8853$; adults $p=0.5137)$. The same was observed after the sixth infestation, when collars had been removed (larvae $p=0.6765$; nymphs $p=0.501$; ; adults $p=0.5335$ ) (Figure 1 ).
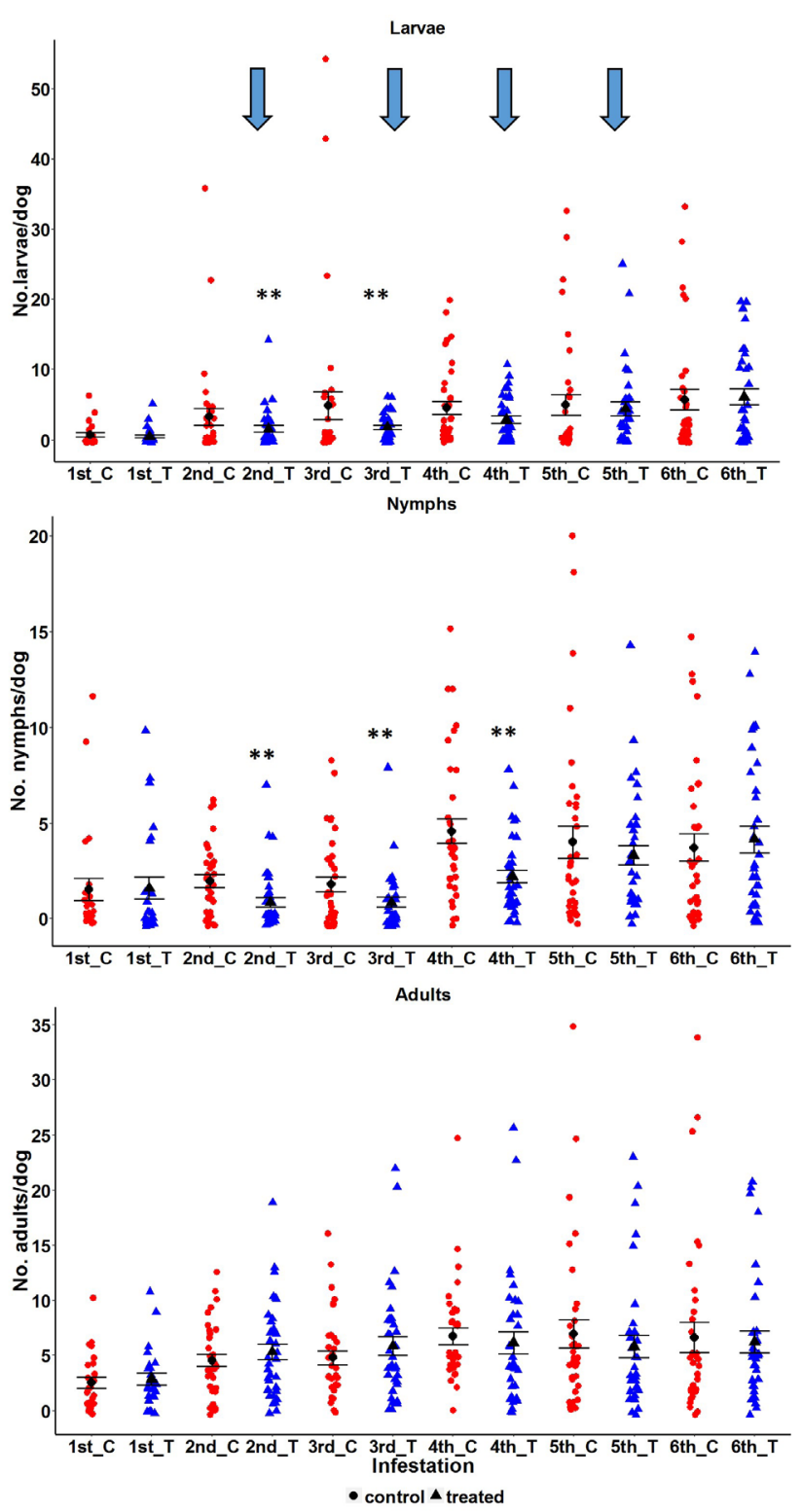

Figure 1. Mean ( ${ }_{ \pm} \mathrm{SE}$, standard error) number of Rhipicephalus sanguineus sensu lato (larvae, nymphs, and adults) retrieved from untreated (control $=$ red circles) and treated (repellent collar = blue triangles) dogs across infestation periods. The repellent collars were attached on the $2^{\text {nd }}$ week and were left in place for 4 weeks (indicated by vertical arrows). Individual data points were shown per week. Significant difference between control and treated dogs is indicated by $p<0.05\left(^{*}\right)$ or $p<0.01\left({ }^{* *}\right)$. 

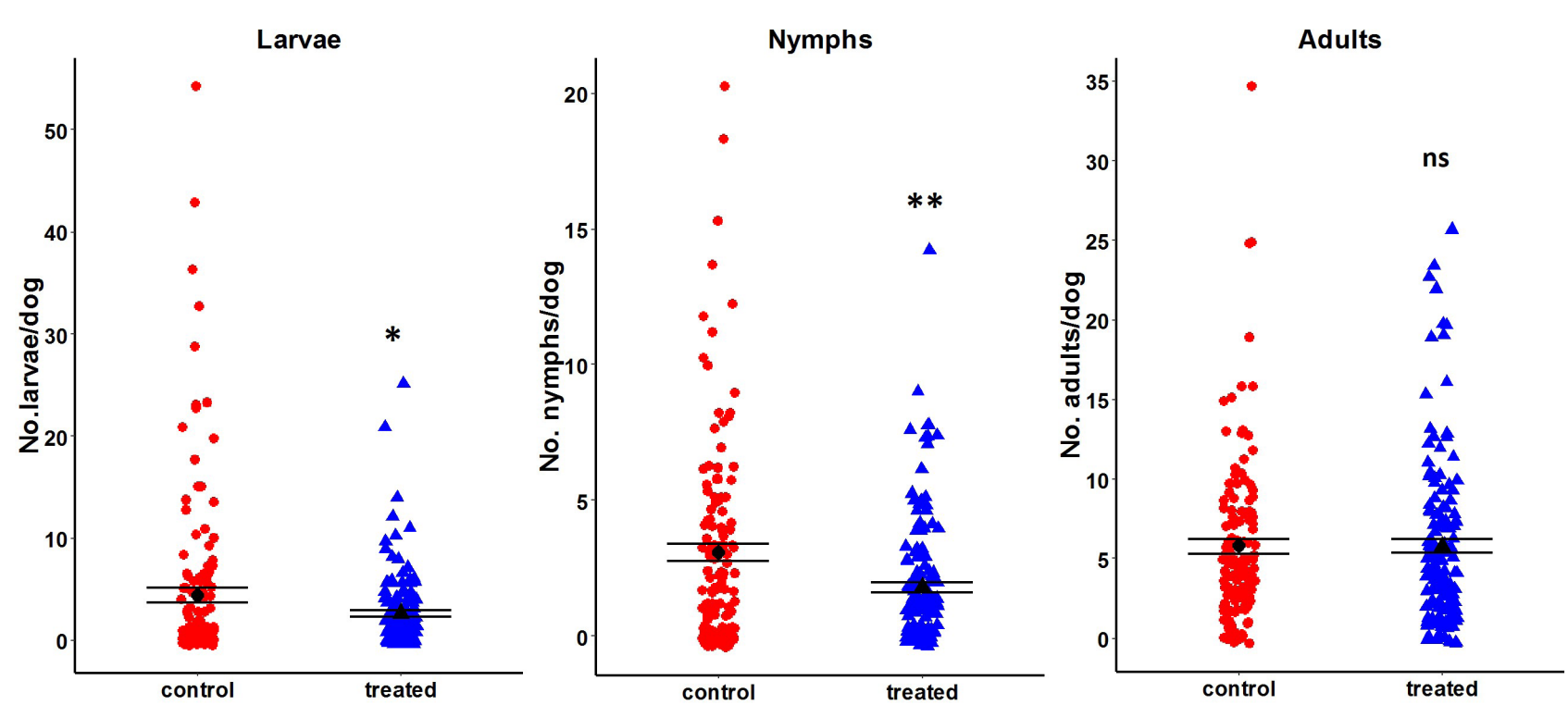

Figure 2. Overall mean $( \pm$ SE, standard error) number of Rhipicephalus sanguineus sensu lato (larvae, nymphs, and adults) retrieved from untreated (control $=$ red circles) and treated (repellent collar = blue triangles) dogs. Individual data points are shown. Significant difference between control and treated dogs is indicated by $p<0.05\left(^{*}\right)$ or $p<0.01\left({ }^{* *}\right)$.

For the weeks during the experiment when dogs wore collars, a significant effect on the number of nymphs and larvae was observed. During the first two weeks after collar attachment, which corresponded to the $2 \mathrm{nd}$ and 3 rd infestations respectively, the number of larvae in the treated group was 2-3 fold lower than in the control group (2nd infestation $p=0.0100$; 3 rd infestation $p=0.0003)$. In the third week after attachment, although the number of larvae was lower in the treated group than in the control, there was no statistical difference $(p=0.0540)$. The number of nymphs in the treated group was almost half of the number in the control group during the three weeks after collar attachment (2nd infestation $p=0.0001$; 3rd infestation $p=0.0080$; 4 th infestation $p<0.0001$ ). However, the number of adults was similar in both groups across all infestations (Figure 1).

Overall, tick loads on dogs wearing the collars containing the repellent formulation were significantly lower for larvae $(\mathrm{p}=0.0123)$ and nymphs ( $\mathrm{p}=0.0003)$ when compared to untreated dogs from the control group. However, for adults, the numbers found in both groups was virtually the same i.e. 808 in the treated group and 807 in the control group ( $p=0.9612$ ) (Figure 2).

\section{Discussion}

The results of this study corroborate results from our earlier work (OLIVEIRA et al., 2017), where it was shown that slow-release formulations of benzaldehyde and 2-hexanone, produced by beagles that are less preferred by brown dog ticks, $R$. sanguineus s. l., can reduce tick loads on susceptible dogs. However, result differences between this study and the earlier work were observed. In our earlier work, we observed repellency against adults across all weeks, although in lower rates than observed for the immature stages. In this study, however, no repellency of adults was observed across any of the weeks. The number of adults released on the walls, and higher counts than the actual number released, was observed in both experiments. It is possible that the same male tick may have been counted either on the same dog in different areas or on different dogs through time, or that nymphs have engorged on dogs and have moulted during the experiment, thereby increasing the number of adults attached on the dogs.

Future work needs to involve more reliable evaluation, including removal of ticks from hosts after counting, as suggested elsewhere (MARCHIONDO et al., 2013). Furthermore, although similar repellency of the immature stages of $R$. sanguineus $s$. l. was observed, a higher persistence of the repellent effect was observed in this study. Formulations remained active for the first three weeks, whereas they were only active for one week in the previous work. The difference in persistence between the two studies may be because in the current study, a higher dose and release rate of the repellent compounds was used. However, what cannot be completely ruled out is that the observed greater persistent effect could be due to an increase in the number of ticks released in the experiments and an improvement in the counting of immature tick stages, compared to Oliveira et al. (2017). Further work is required to rule out the effect of tick numbers.

During the first three weeks of the study, the ratio of benzaldehyde: 2-hexanone release from the formulations was roughly similar to that found naturally in beagles (OLIVEIRA et al., 2016). However, from the 4th week, the ratio of release was markedly different, which coincided with a reduction in tick repellency. In the study, the repellents were released in a background of attractant VOCs from English Cocker Spaniel dogs, with the dogs being perceived, from an olfactory perspective, as less-preferred beagles (INOKUMA et al., 1997; JITTAPALAPONG et al., 2000; LOULY et al., 2009; LOULY et al., 2010). From the results, we 
hypothesize that relative amounts, rather than absolute amounts, of repellent release from the slow-release formulations, are important for tick repellent activity, and that avoidance of less-preferred hosts by ticks relies on olfactory-mediated perception of specific blends of volatile cues from less preferred hosts. Although beagles are considered as less preferred by $R$. sanguineus s. l., they are still naturally parasitized (LORUSSO et al., 2010; DANTAS-TORRES \& OTRANTO, 2011).

Based on the results in our study, we propose that repellent allomones produced by beagles can decrease loads of $R$. sanguineus s. l. on susceptible dogs, but that they cannot control ticks by themselves. The push-pull strategy, also known as the stimulo-deterrent diversionary strategy, has been described as a route by which to manage animal pests, and consists of two distinct phases: a push phase which aims at repelling or deterring parasites of resources such as animals, through the use of stimuli that act as repellents for these parasites or mask the presence of the host, and a pull phase, which aims to use either highly attractive stimuli that may indicate host presence, or pheromones, to attract and divert the parasites of the resources to be protected. Currently, this strategy is being developed for the sustainable management of tsetse flies, Glossina morsitans morsitans, that vector the trypanosomiasis parasite affecting millions of cows in sub-Saharan Africa (COOK et al., 2007; ICIPE, 2017). To our knowledge, this type of strategy has yet to be attempted for the management of ectoparasitic ticks affecting companion animals. New experiments are needed to explore the possibility of using repellent formulations in conjunction with an attractant trap and an acaricide, as proposed in the push-pull strategy, for $R$. sanguineus s. 1. management on domestic dogs.

\section{Conclusion}

Slow-release formulations that release benzaldehyde and 2-hexanone in higher doses than in our previous study can decrease the load of immature tick stages on artificially-infested dogs for up to three weeks, but cannot increase the efficacy of the repellents.

\section{Acknowledgements}

We thank the National Council of Technological and Scientific Development - CNPq, Brazil, for its financial support (Grant no. \#/2013-9) and for supply a Scholarship to LMFB (\#/2015-0). Rothamsted Research receives grant-aided support from the Biotechnology and Biological Sciences Research Council (BBSRC) of the United Kingdom.

\section{References}

Bett MK, Saini RK, Hassanali A. Repellency of tsetse-refractory waterbuck (Kobus defassa) body odour to Glossina pallidipes (Diptera: Glossinidae): assessment of relative contribution of different classes and individual constituents. Acta Trop 2015; 146: 17-24. http://dx.doi.org/10.1016/j. actatropica.2015.02.017. PMid:25746973.

Birkett MA, Agelopoulos N, Jensen KMV, Jespersen JB, Pickett JA, Prijs $\mathrm{HJ}$, et al. The role of volatile semiochemicals in mediating host location and selection by nuisance and disease-transmitting cattle flies. Med Vet Entomol 2004; 18(4): 313-322. http://dx.doi.org/10.1111/j.0269283X.2004.00528.x. PMid:15641996.

Borges LMF, Duarte SC, Louly CCB. Cattle tick differentiates between the odors of Holstein Friesian and Nelore cattle. Cienc Rural 2015a; 45(11): 2023-2025. http://dx.doi.org/10.1590/0103-8478cr20150010.

Borges LM, Oliveira JG Fo, Ferreira LL, Louly CC, Pickett JA, Birkett MA. Identification of non-host semiochemicals for the brown dog tick, Rhipicephalus sanguineus sensu lato (Acari Ixodidae), from tick-resistant beagles, Canis lupus familiaris. Ticks Tick Borne Dis 2015b; 6(5): 676682. http://dx.doi.org/10.1016/j.ttbdis.2015.05.014. PMid:26103925.

Cook SM, Khan ZR, Pickett JA. The use of push-pull strategies in integrated pest management. Annu Rev Entomol 2007; 52(1): 375-400. http:// dx.doi.org/10.1146/annurev.ento.52.110405.091407. PMid:16968206.

Dantas-Torres F, Otranto D. Rhipicephalus sanguineus on dogs: relationships between attachment sites and tick developmental stages. Exp Appl Acarol 2011; 53(4): 389-397. http://dx.doi.org/10.1007/s10493-010-9406-4. PMid:20957414.

Eiden AL, Kaufman PE, Oi FM, Allan SA, Miller RJ. Detection of permethrin resistance and fipronil tolerance in Rhipicephalus sanguineus (Acari: Ixodidae) in the United States. J Med Entomol 2015; 52(3): 429436. http://dx.doi.org/10.1093/jme/tjv005. PMid:26334817.

Graf JF, Gogolewski R, Leach-Bing N, Sabatini GA, Molento MB, Bordin EL, et al. Tick control: an industry point of view. Parasitology 2004;129(7 Suppl Suppl): S427-S442. http://dx.doi.org/10.1017/ S0031182004006079. PMid:15938522.

Inokuma H, Tamura K, Onishi T. Dogs develop resistance to Rhipicephalus sanguineus. Vet Parasitol 1997; 68(3): 295-297. http://dx.doi.org/10.1016/ S0304-4017(96)01071-0. PMid:9066074.

International Centre of Insect of Physiology and Ecology - ICIPE. Tsetse repellent technology [online]. Nairobi: ICIPE; 2017 [cited 2017 May 23]. Available from: http://www.icipe.org/impacts/products/tsetserepellent-technology

Jensen KMV, Jespersen JB, Birkett MA, Pickett JA, Thomas G, Wadhams LJ, et al. Variation in the load of the horn fly, Haematobia irritans, in cattle herds is determined by the presence or absence of individual heifers. Med Vet Entomol 2004; 18(3): 275-280. http://dx.doi.org/10.1111/j.0269283X.2004.00506.x. PMid:15347395.

Jittapalapong S, Stich RW, Gordon JC, Wittum TE, Barriga OO. Performance of female Rhipicephalus sanguineus (Acari: Ixodidae) fed on dogs exposed to multiple infestations or immunization with tick salivary glands or midgut tissues. J Med Entomol 2000; 37(4): 601-611. http:// dx.doi.org/10.1603/0022-2585-37.4.601. PMid:10916303.

Lorusso V, Dantas-Torres F, Lia RP, Tarallo VD, Mencke N, Capelli G, et al. Seasonal dynamics of the brown dog tick, Rhipicephalus sanguineus, on a confined dog population in Italy. Med Vet Entomol 2010; 24(3): 309-315. PMid:20557458.

Louly CC, Soares SF, Nóbrega Silveira D, Guimarães MS, Borges LM. Differences in the behavior of Rhipicephalus sanguineus tested against resistant and susceptible dogs. Exp Appl Acarol 2010; 51(4): 353-362. http://dx.doi.org/10.1007/s10493-009-9334-3. PMid:20091335.

Louly CCB, Soares SF, Silveira DN, Neto OJ, Silva AC, Borges LMF. Differences in the susceptibility of two breeds of dogs, English cocker spaniel and beagle, to Rhipicephalus sanguineus (Acari: ixodidae). Int J Acarol 2009; 35(1): 25-32. http://dx.doi.org/10.1080/01647950802655251. 
Marchiondo AA, Holdsworth PA, Fourie LJ, Rugg D, Hellmann K, Snyder DE, et al. World Association for the Advancement of Veterinary Parasitology (W.A.A.V.P.) second edition: guidelines for evaluating the efficacy of parasiticides for the treatment, prevention and control of flea and tick infestations on dogs and cats. Vet Parasitol 2013; 194(1): 84-97. http://dx.doi.org/10.1016/j.vetpar.2013.02.003.

Moral AR, Hinde J, Demétrio CGB. Half-Normal plots and overdispersed models in R: the hnp package. J Stat Softw 2017; 81(10): 1-22. http:// dx.doi.org/10.18637/jss.v081.i10.

Oliveira JG Fo, Ferreira LL, Sarria ALF, Pickett JA, Birkett MA, Mascarin GM, et al. Brown dog tick, Rhipicephalus sanguineus sensu lato, infestation of susceptible dog hosts is reduced by slow release of semiochemicals from a less susceptible host. Ticks Tick Borne Dis 2017; 8(1): 139-145. http:// dx.doi.org/10.1016/j.ttbdis.2016.10.010. PMid:28340941.

Oliveira JG Fo, Sarria ALF, Ferreira LL, Caulfield JC, Powers SJ, Pickett JA, et al. Quantification of brown dog tick repellents, 2-hexanone and benzaldehyde, and release from tick-resistant beagles, Canis lupus familiaris. J Chromatogr B Analyt Technol Biomed Life Sci 2016; 1022: 64-69. http:// dx.doi.org/10.1016/j.jchromb.2016.03.014. PMid:27085013.
Pickett JA, Birkett MA, Dewhirst SY, Logan JG, Omolo MO, Torto $B$, et al. Chemical ecology of animal and human pathogen vectors in a changing global climate. J Chem Ecol 2010; 36(1): 113-121. http:// dx.doi.org/10.1007/s10886-010-9739-9. PMid:20119869.

R Core Team. A language and environment for statistical computing [online]. 2015. [cited 2017 Nov 10]. Available from: http://www.R-project.org/.

Rodriguez-Vivas RI, Ojeda-Chi MM, Trinidad-Martinez I, Pérez de León AA. First documentation of ivermectin resistance in Rhipicephalus sanguineus sensu lato (Acari: Ixodidae). Vet Parasitol 2017; 233: 9-13. http://dx.doi.org/10.1016/j.vetpar.2016.11.015. PMid:28043394.

Silva SR. Levantamento epidemiológico de carrapatos em cães assistidos em duas unidades privadas de serviço de saúde animal na Zona Oeste da cidade do Rio de Janeiro. [dissertação]. Rio de Janeiro: Universidade Federal Rural do Rio de Janeiro; 2016.

Sonenshine DE, Roe RM. Biology of ticks. 2nd ed. Oxford: Oxford University Press; 2014. Overview: ticks, people and animals; p. 3-16. 